\title{
A HISTORY WRITTEN WITH FOUR HANDS
}

\author{
Renata Cardoso Belleboni Rodrigues ${ }^{1}$
}

1993. Waiting for the results of the entrance exam to join the History course of Unesp, Franca's campus. Even before I realized the results, I was thinking to do masters in Ancient Greece not even knowing what a postgraduate was. November of 1996, all set to the TCC defense patiently and competently oriented by teacher Dr. Margarida Maria de Carvalho. In the text, the defense that tragedy was the mirror of greek society. Not a perfect reflex but very close to reality. The appointments and adjusts been made by the board alerted me about the concept of reflex and started a wish to understand the representation one, beyond presenting me a captivating historiographic theory. The shape and the extension of the culture term showed along the arguing made me belive that was the way to go in possible future research. I realized it would be a harsh path because it brings the traces of Marxist historiography or a more sociological one from the teachers who ministered the graduation disciplines. The only certain was: I had a lot to learn.

1997 was a water divisor. When my advisor sent my text and a presentation letter to one of the authors I have a great admiration, the teacher Pedro Paulo Funari alerted me: "he is a quick responder." Four months later and nothing. I was sure that my text had not provided a good reading. But the answer arrived and in the envelope a lot of stamp from France. The correspondence was desviated, it had crossed the Atlantic ocean twice before it gets to France. In the text there was appointments, corrections and indications of reading. In a separate paper, one first meeting set for 14 of july at 11 o'clock at IFCH. Day and hour setted, I waited for that conversation, anxious, maybe the same feeling of a boy when he's about to meet his football idol. At 11:03 a.m the teacher presents himself and apologize for the delay. Delay ? In this first I realized seriousness of what it will come in case he decided to guide me. One hour and a half later I want out of his office with a very different proposal than I expected. My intention was to continue studding greek theater, but I started to read Jean-Pierre Vernant's work to know, understand spread his propositions, his Ancient Greece representation. In

\footnotetext{
1 Assistant Professor, Municipal Higher Education Braganca Paulista Foundation, Bragança Paulista, Brazil. E-mail: re.medusa@gmail.com
} 
the first moment, I believed that it would be easy... since when understand an author's work is easy? Two thoughts kept conflicting along each page readed: or my future advisor was testing me or he believed in me enough to pass along assignment for me, almost a feat. In every single exchanging of letter we made, when I sent my files and text attempt, new readings suggested, questioning made, corrections (even orthographic). I hadn't even defined exactly what I would approach in the project that would be presented only in the end off 1999 and orientations kept going.

October of 1997. In a Congress from SBEC that occurred at USP we had a new meeting. Disinterestedly and, with some embarrassment I took a draft off my pre-project. The model was passed by be own teacher, and what was my surprise: at the end of the reading, sugestions, changes here and there and the deadline for presentation of the project was one month short. November, subscription. March of 1998, a lot of euphoric entrants with a new realite. Many of them like me, sons of institutions from the state and around country, waiting for the moment when the library of IFCH would be come our second address. Many like me, introduced for a group of teacher who defended a cultural history. During the classes of teacher Funari and along the orientations, what was new before became so natural that it seemed (and it still does) that there is no other way to see history. One more lesson was always there: it's necessary to know and seek to understand the others historiografics currents and also the philosophical, archaeological and sociological ones, because to criticize you need to have a background, to understand history you have to accept that she is not alone in the endeavour of understanding human culture. This learning and impulse for more and more readings I own to me adviser.

For three years we had a lot of classes, seminars, congresses in and out of Unicamp, new authors to read, to know in person, a lot of concepts to understand. But also a lot of coffes, wine occasionaly, lunch with everyone, a lot of talk and left. Each day the bound of friendship became tighter and I didn't realized how necessary it would become ahead. With the qualification set ant text delivered to the board, a last talk and one advice: "keep calm, I followed the process, you wrote the text, know between the lines, the board is composed by friends and I will interfere if necessary." And it worked! I was calm to this moment of corrections, suggestions and critics. And what a surprise when the severe questions where made by the first member of the board. Critcs to the written, to the format, to the proposal and even to the result presented there. But I was calm, after all, my advisor was there, attentive, taken notes of every word 
he said. It was when he second one slap with his hand on the desk and said: "How do you interview Vernant, the object of your study and not tell the story here? I want to know it all." Is ws a moment of relief in the middle of the tension. New observations and contributions. In the end, I had the great pleasure to hear Pedro Paulo Abreu Funari to interfere in my defense. He clarified point by point to all questionings made. Promise made, promise accomplished.

The qualification was done and, as usual, a coffee to new orientations in the path to my defense. We talked about the strong critics and suggestions. I barely knew about the development of my qualification. Everyone there was scared by the first arguments, because of the way they were made and because of the tone they were said. A college almost gave up of his own qualifications which would be happening in a few days. While things got hotter to my side and my advisor's side, I went to my parent's house located in the interior of the state. In the way, the doubted if I really had satisfied the members of the board and at the same time I was tranquilized by the words of Funari. I barely got in Ribeirão Preto, where my boyfriend lives, and my parents called me saying that the teacher wanted to talk to me. Minutes later, friendly words made me assure that I not only had an advisor but also a friend by my side. As I heard his words, I was written down on a little paper on the desk. I still keep this recordation with me.

In my doctorate degree was not different. Now I was learning with Funari how to read images. Medusa changed, in each author discovered and with the new considerations and orientations. The research was gaining shape and the pieces where fitting in a mythological, symbolical and cultural puzzle. Many times I doubted the path taken... many times I was redirected to the right way by the friendly hands of the one who showed me how complex and fascinating history can be.

It was during these path that difficult decisions were made. I was contemplated with a scholarship from Fapesp during my master degree and now I would try this again or I will accept the offer to coordinate the History course of the University of Science and Letters of Bragança Paulista where I am for 18 years teaching Ancient History? His advices were precise: "Think in your career", "research, teaching and administration can walk side by side", "think about the contributions that you will be able to bring to your colleges and students". Coordination accepted, the research continued and the teaching was improved. Good advices produce good results. 
A real friend invites other friends to qualification and defence. How great it was to have may masters and doctorate colleges in my board. Easy, no? Like me, they also learned with the master. They knew what to demand and how to do it. Another gift received was the presence of my first advisor on the board. By the end of it all, the promise of master degree was renovated: again words on my defence were said. I also keep them with affection. The story was not finished. I had the pleasure to be a part pf the boards of new students of the professor. Be like substitute or a member, I relived in the reading pages the orientations received so may times. It is possible to know his marks in different texts.

To finish, I have to reinforce that I am a researcher that I am today because I had an example. I am the teacher that $\mathrm{T}$ am today because I had a good example. I can even say that the person I became is a result of this same example. Dear friend Pedro Paulo, thank you for the lessons, defence, friendship, for this history pages written with four hands. 